\title{
Editorial
}

\section{The Union and Turkey: The Hard Way}

On 3 November 2002, the Turkish elections brought an overwhelming victory for the Justice and Development Party (Adalet ve Kalkinma Partisi-AKP), the first party since 1987 to secure a clear majority in Parliament. It triumphed on a ticket including Turkey's entry into the European Union. Valéry Giscard d'Estaing then grasped the occasion and his newfound status of Convention chairman to vent an old conviction (reported in Le Monde of 9 November) that Turkey's entry into the EU would be 'the end of European Union'. It was a good thing that hardly anyone in the Convention took notice of this irrelevant and even irresponsible step. But in the eyes of the public a link between the Constitution and Turkey's accession had been established beyond doubt. It could only be undone by European leaders in power (first by Chirac) at the cost of heavy concessions to populist demands. France will have a separate referendum on Turkey and on other accessions thanks to a constitutional amendment (see Carcassonne's contribution to this issue). Other countries will follow no doubt.

Two years after the Turkish elections, on 16 and 17 December 2004, the European Council dealt a blow to Giscard's and others' hopes of undermining Turkey's candidacy. It resolutely refused to downgrade the invitation to one for anything short of full membership. It is not for this journal to plead for or against Turkey's membership in the Union. Our ambition is to raise points of constitutional interest, in a wide sense, from the events and from the readings they allow. If a constitution is all about the organisation of public responsibilities, a European constitution is about organising public responsibilities at the European level. This is the central constitutional theme involved in the events and to be developed now.

First, however, one of the standard arguments against Turkey's accession, as again voiced by Giscard and reported in Le Monde, should be addressed. It is the point that the Union cannot digest yet another enlargement without becoming ungovernable. This argument has recurred at each enlargement and has been contradicted each time by the facts. The 1973 accession of Britain, Ireland and Denmark upset the Communities' geo-political structure much more than will the 
Turkish accession. It did not lead to a governance problem but instead to innovation, to wit the creation of the European Council, and to direct elections and budgetary powers for the European Parliament. The Spanish and Portuguese accessions in the eighties came with Single European act (bringing the European Parliament's legislative role and its right of assent to further accession). The entry of Eastern Europe, prompted by the Berlin Wall's coming down on 9 November 1989, was accompanied by the series of treaties between Maastricht and Rome, involving the creation of the Union and ultimately of the Constitution.

Nor is this special for the Union. Throughout constitutional history, the incorporation of newcomers into an existing polity has been the one main driving forces not only of economic, but also of political and structural, including legal, innovation. In Rome's history, it goes without saying. In our Middle Ages, the Burghers and their cities emancipated themselves from the Feudal order. It also goes for immigrants coming from outside, as in the US experience. Europe itself has always been an area of mass (internal) migration well before the EC. More Italians, for example, migrated in the last two centuries to other European countries than to the US.

What innovation Turkey's accession will bring to the Union we do not know, but the fear or even certainty (as Giscard's) of the Union regressing to a mere market place amounts to a straight denial of even the possibility of innovation as arising from migration and incorporation. It is possible that the Union will not succeed in digesting the Turkish accession. But to hold this as inevitable or certain is no more than rhetoric. And surely if Turkish accession fails, the decisive factors will not be of static geo-political nature, such as Turkey being too large and populous and its capital being outside of Europe, as Giscard claims. If it fails, it will be from a lack of political capacity in the Union to face coming global, external, political developments and crises.

These developments cannot be predicted with any degree of probability, let alone with certainty. To face or anticipate them there is the Union's incipient common foreign policy, of which enlargement is, precisely, the one most successful chapter, the spearhead.

Back to responsibilities. The task to decisively organise responsibilities in a complex and delicate political setting is a matter for executive authority. In the Union, this claim of authority is increasingly centring on the presidency of the Council and European Council. The Netherlands were in charge, this fall. While in the Barroso drama, unrolling during this same period, the Dutch presidency failed in the organisation of collective responsibility in the face of the crisis, as appears from different contributions in this volume on that subject (notably Van Keulen's and Beukers'), the Turkey decision was an unmistakable success for the Dutch. They demonstrated leadership in a complex layered setting, with great risks of breakdown. The result teaches lessons on European government. 
In order to learn what this involved, it is best to focus on what had to be overcome for the decision to be taken. At the Helsinki summit of December 1999, Turkey had been given the status of a 'candidate country destined to join the Union'. At the Copenhagen summit of 2002, a good month after the above-mentioned Turkish elections (and after Schröder's surprise re-election in Germany thanks in part to Turkish voters), on the initiative of Chirac and Schröder it was decided to name a date for the further decision, yes or no, to start negotiations: the European Council of December 2004. This threw the ball into the Dutch court.

Was there a choice for Dutch PM Balkenende and, during his long sick leave, for deputy PM Zalm, a well-known sceptic about Turkey? Probably not. For Europe's president merely to entertain hesitations as to Turkey's candidacy would have been tantamount to opening a European Pandora's box of populisms. Whatever their personal convictions, they had no choice but to undertake their European responsibilities. First the pressure needed to be brought on the home front. The PM's Christian Democrats were opposed to Turkey's entry and the Liberal conservatives were hesitant. Of the six months of Dutch presidency, five were needed for a hard fought mandate from the Cabinet and the Parliament to go ahead and take the European lead. In that same period, on 2 November 2004, Dutch film maker Theo van Gogh was beastly murdered in Amsterdam by a radical Muslim. The murderer had pinned a note to Van Gogh's body which read: 'I know for certain that you, O Europe, are doomed'. Only on 24 November, with the country aflame over the murder but with no more than three weeks to go to the scheduled European decision, the national mandates were finally secured. If increasingly European responsibilities will be seen directly and heavily to weigh on and even to determine a national political stance (and enhance national politics), this is a good example.

In the final meeting of 16-17 December 2004, two problems were to be solved. The first, both most superficial and most acute, suddenly surged at the meeting but was skilfully put to rest by Dutch diplomacy. It concerned the modality of Turkish acknowledgement (to avoid the word recognition) of the Republic of Cyprus. The second, cutting deepest into European politics, concerned the definition of Turkey's future relation to Europe. Powerful and shrewd forces across Europe, including leading Christian Democrats in the European Parliament and German party chief Angela Merkel, had converged on a second best final perspective for Turkey, a 'Privileged partnership'. This was also Giscard's idea.

Not the mere fact that this perspective failed to find a way into the formulae finally adopted by the European Council is most remarkable. It is telling with what determination the Privileged partnership was explicitly rejected, first in the European Parliament and then in the European Council. On 15 December, in a double vote in the European Parliament, the Christian Democrat initiatives were 
killed off massively. Two days later, on 17 December, the European Council concluded its own negotiations in the same vein, by isolating and neutralising the chief and most decidedly protagonist of the idea in its midst, Austria, in the person of its Christian Democrat PM Wolfgang Schüssel.

Apart from providing, after the Barroso drama, another glimpse of an adult European political life (in which, remarkably, the European Right again accumulated blunders and defeats), the events are a lesson in responsibility. In 2002 no one could even imagine what constitutional improvements the incoming Islamist Turkish Erdogan government would be capable of. Giscard's deft refusal of Turkey was, in those days, a safe bet. Not to go along with this safe option but to allow the facts of Turkish reform capacity to speak for themselves, and they would, for all to read in the European Commission report of 6 October 2004, was a matter of political good sense, one of openness to the future and to the world outside the Union. What is the difference?

Political scientist Robert Putnam in his latest book (Better Together) develops a distinction between two forms of 'social capital' (a term he invented and vented in his previous best seller Bowling Alone). Social capital is, simply, the value of stable human relationships. There is that social capital created between people who have much in common: bonding social capital, and there is that, more difficult to find and superior in quality, between people of different belongings: bridging social capital. Europe's Turkish choice has been one for the hard way. In Putnam's terms, it is a choice against just bonding, one for building bridges.

The decision on Turkey is a bold one. But in the way it was taken, in the neat refusals and the sharp convictions it expressed, including the European Parliament's full participation, this decision heralds just that political capacity for the Union needed to parry the inevitable difficulties it is bound to meet.

JWS/WTE 